\title{
13. SUBSIDENCE HISTORY OF BASEMENT SITES AND SITES ALONG A CARBONATE DISSOLUTION PROFILE, LEG 115
}

\author{
Gregory R. Simmons ${ }^{2}$
}

\begin{abstract}
Subsidence history analyses in this investigation rely on age-depth relationships for ocean crust as the basis for the time vs. depth format. Leg 115 sites are located on residual depth anomalies along the volcanic trace of the Réunion hotspot. A key assumption is that, although basement is emplaced at anomalously shallow depths compared with normal ocean crust, subsidence proceeds at rates predicted by the age-depth relationship. The lithology of the basalts and immediately overlying sediments supports the results of this investigation. The tectonic setting in which hotspot volcanism occurred (near-ridge axis to intraplate), suggested from geochemistry of the basalts, does not appear to be a major factor in determining the predictability of subsidence history.
\end{abstract}

\section{INTRODUCTION}

A principal objective of Ocean Drilling Program (ODP) Leg 115 was to investigate the history of biogenic carbonate dissolution as a function of increasing water depth, including the "carbonate compensation depth" (CCD), below which biogenic carbonate does not accumulate. This objective is addressed along a bathymetric transect across the northern Mascarene Plateau and the Madingley Rise, stretching from Site 707 at a water depth of $1552.3 \mathrm{~m}$ to Site 711 at $4428.2 \mathrm{~m}$ (Fig. 1). Any meaningful attempt at historically reconstructing depth-dependent conditions in the ocean, as seen by facies relationships across a particular area, requires a knowledge of the bathymetry during which the facies were deposited. It is the intention of this work to provide insight into the paleobathymetry of this "carbonate dissolution profile."

Subsidence history analysis provides a means to portray the architecture of a sedimentary basin in a time-depth format. The method applied in this investigation relies on the subsidence rates for ocean crust (Parsons and Sclater, 1977) as the basis for the time-depth relationship. This approach, generally referred to as "backtracking," contrasts with "backstripping," in which sediment layers are stripped off, one by one, starting at the top of the section, to calculate the subsidence of basement not caused by loading.

\section{PREVIOUS INVESTIGATIONS}

Parsons and Sclater (1977) approximated the age-depth relationship for ocean crust using two theoretical curves that best fit observed age and sediment load-corrected depth of basement underlying the world oceans (Fig. 2). Depth initially increases as the square root of age for roughly the first $70 \mathrm{~m}$.y. and increases in a negative exponential fashion thereafter. In light of plate tectonic theory, this relationship can be envisioned as subsidence caused by thermal contraction of Mid-Ocean Ridge basalt (MORB) as it moves away from the spreading ridge. The 2500 -m depth for zero-age crust corresponds to the average depth to world mid-ocean ridge crests. Decreasing subsidence rates with time are thought to represent the increasing importance of

\footnotetext{
1 Duncan, R. A., Backman, J., Peterson, L. C., et al., 1990. Proc. ODP, Sci. Results, 115: College Station, TX (Ocean Drilling Program).

2 Department of Oceanography, Texas A\&M University, College Station, TX 77843, U.S.A.
}

small-scale thermal convection from below compared with cooling from above (Parsons and McKenzie, 1978). The maximum depth of $6400 \mathrm{~m}$, therefore, represents the depth at thermal equilibrium between loss of heat from above and convection of heat from below.

Sclater et al. (1985) showed that roughly $60 \%$ of the world ocean crust lies within approximately $10 \%( \pm 400 \mathrm{~m})$ of the total subsidence predicted from the age-depth relationship. Areas lying outside of this envelope are termed "residual depth anomalies." Positive anomalies (e.g., those occurring above the depth predicted by the age-depth relationship) are normally attributed to thermal convective plumes or "hotspots" rising from the mantle. The Mascarene Plateau, across which the carbonate dissolution profile was drilled, is such an anomaly, formed as the crust underlying the western Indian Ocean drifted across a hotspot now centered under Réunion Island (Fig. 1).

The complexity of the subsidence history for residual depth anomalies is determined largely by the setting in which they are formed. Anomalous thermal activity occurring at or near a mid-ocean ridge crest creates an excess pile of basalt attached to the newly created segment of ocean plate. Subsidence presumably occurs in a predictable fashion according to the age-depth relationship along with the plate to which it is attached. Residual depth anomalies formed in intraplate settings interrupt the predictable phase of subsidence in progress.

\section{METHODS}

The methodology used in this investigation is slightly modified from that presented by Sclater et al. (1985). The data used for sites encountering basement include the present depth of basement and the radiometrically determined age of basement (Fisk et al., 1989). Most of the sites along the carbonate dissolution profile did not encounter basement. In this case, the age of basement is estimated from the distance of each site to the Carlsberg Ridge. ODP Site 707 and Deep Sea Drilling Program (DSDP) Site 236 (Vincent and Gibson, 1974), both of which are reliably dated basement sites, are tie points for basement ages vs. distance from the ridge crest (Fig. 1). The hypothetical depths to basement are estimated by extrapolating assumed sedimentation rates from the bottom of the holes to the estimated age of basement. These depths tend to exceed basement depths picked from seismic records collected during site approaches (see "Underway Geophysics" chapter in Backman, Duncan, et al., 1988), but the difference in each case is less than $10 \%$ of the estimated depth. The final output includes time-depth curves of basement or hypothetical basement, and the sediment/water interface. 


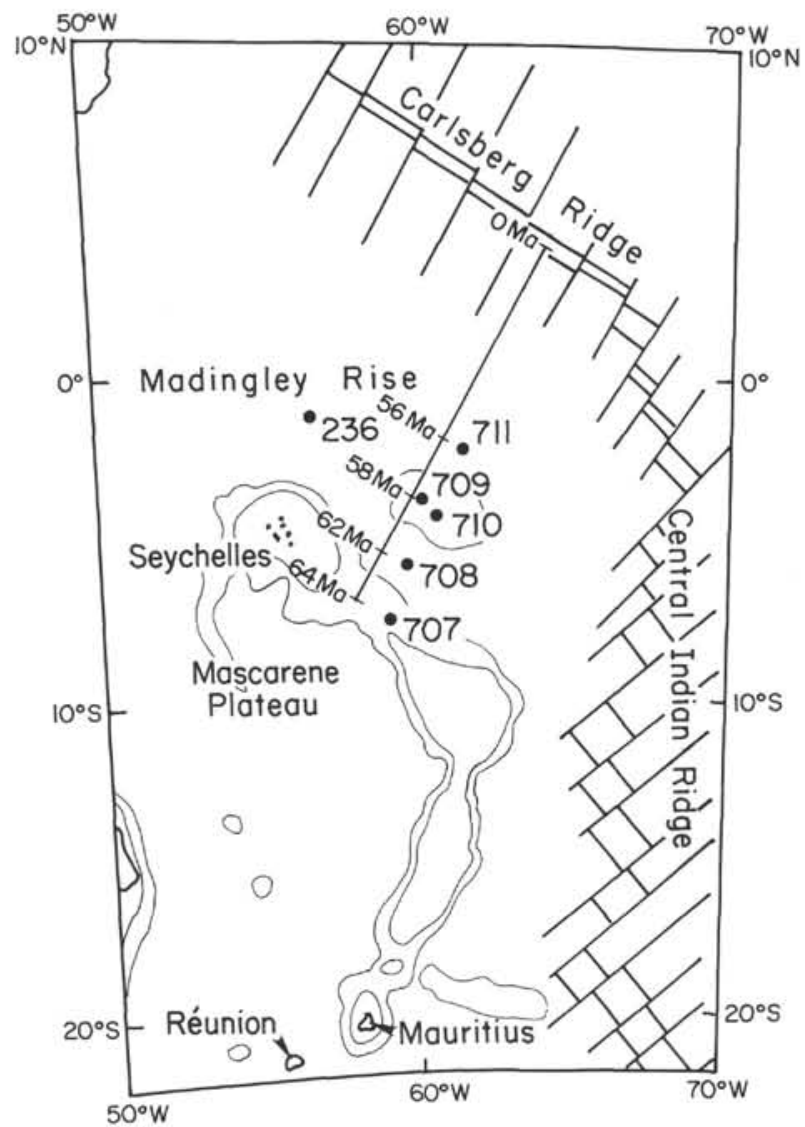

Figure 1. Physiographic map centered on the Mascarene Plateau, showing the location of sites along the carbonate dissolution profile. Ages of nonbasement sites (Sites 708-711) are estimated from distance to the mid-ocean ridge crest compared to Site 707 and DSDP Site 236.

The first step is to correct the depth of basement isostatically by removing the load created by the overlying sediments. The sediment load correction, $(\mathrm{m})=\mathrm{s}(\rho \mathrm{s}-\rho \mathrm{w}) /(\rho \mathrm{m}-\rho \mathrm{w})$, is derived in Fig. 3. The sediment density $(\rho s)$ is the mean density for the total thickness of the sediment column, determined by summing the matrix density $\left(\rho \mathrm{ma}=2.71 \mathrm{~g} / \mathrm{cm}^{3}\right)$ and fluid density $\left(\rho \mathrm{w}=1.03 \mathrm{~g} / \mathrm{cm}^{3}\right)$ through the sedimentary section according to the porosity-depth relationship (Fig. 4) calculated from the DEPOR algorithm of Stam et al. (1987). The mantle density $(\rho \mathrm{m})$ is assumed to be $3.3 \mathrm{~g} / \mathrm{cm}^{3}$.

The next step is to determine the depth of emplacement according to the age-depth relationship of ocean crust (Parsons and Sclater, 1977) using the estimated age and corrected depth of basement. All basement age estimates for Leg 115 sites were $<70 \mathrm{Ma}$ and therefore fell within the initial phase of the relationship, with the crust subsiding as the square root of age. The expression used to calculate the depth of emplacement is $D=B$ - $350 \sqrt{A}$, where $D, B$, and $A$ are the depth of emplacement, corrected depth of basement, and age of basement, respectively.

The final step is to subside basement progressively from the time of emplacement to the present in 1-m.y. increments. In addition to subsidence caused by thermal contraction, the crust is progressively loaded by the total sediment thickness at each increment. The contribution of loading from the sediment thicknesses involved is minor in comparison to thermal contraction of the young crust. The depth of the sediment/water interface is traced by subtracting the thickness of the decompacted sedi-

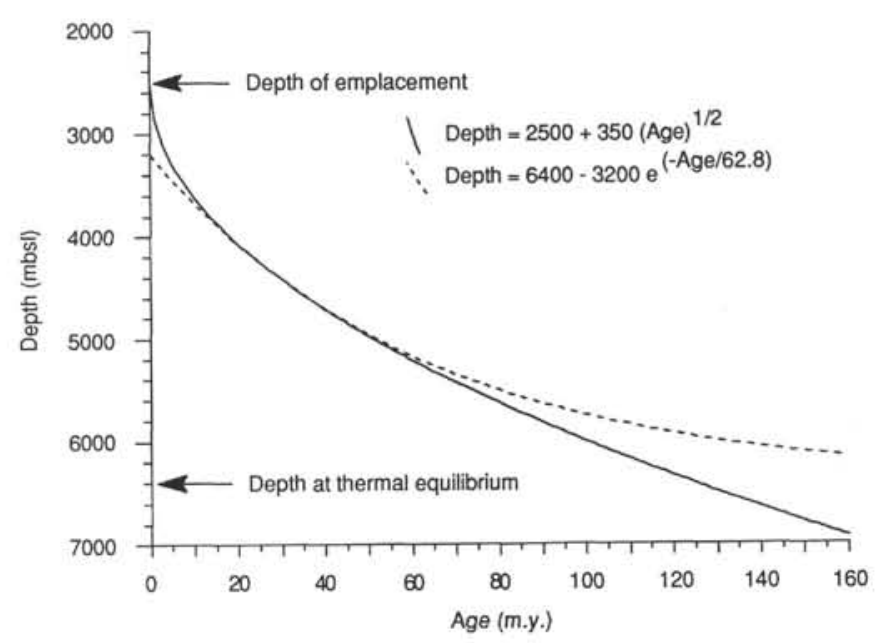

Figure 2. Age-depth relationship for normal ocean crust (Parsons and Sclater, 1977). Two-part relationship: (1) solid line applies for initial subsidence ( $0-70-\mathrm{m} . \mathrm{y}$. old crust), and (2) dashed line applicable thereaf$\operatorname{ter}(>70$ m.y.).

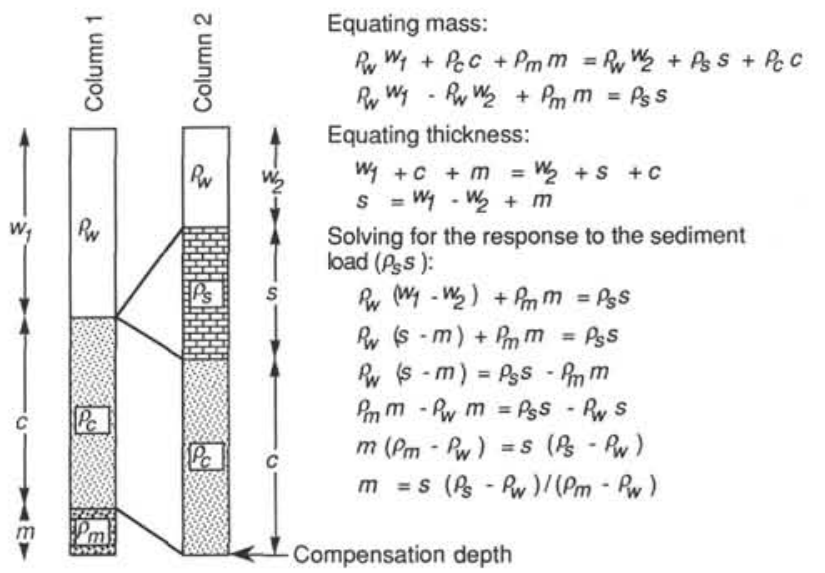

Figure 3. Airy isostatic model for correcting crustal depth from overlying sediment load. The distance $(m)$ represents the response of the crust to a sediment load $\left(\rho_{s} s\right)$, in which $\rho_{w}, \rho_{s}, \rho_{c}$, and $\rho_{m}$ are the density of water, sediment, ocean crust, and mantle, respectively, and $w_{1}, w_{2}, s, c$, and $m$ are the thickness of the water before sediment accumulation, water after sediment accumulation, sediment, ocean crust, and mantle above the depth of compensation, respectively.

ment column from the corresponding depth of basement. Decompaction of the sediment column is applied according to the porosity-depth relationship (Fig. 4).

\section{RESULTS}

Basement at all of the basement sites was emplaced at depths above the $2500 \mathrm{~m}$ expected for normal ocean crust (Fig. 5). The data used to generate these curves is summarized in Table 1. According to these analyses, oceanic basement at Sites 707 and 715 was emplaced at depths very near to above sea level, and below sea level at Sites 706 and 713 .

Most of the sites along the carbonate dissolution profile did not reach basement, Site 707 being the only exception. The data used for the analyses of these nonbasement sites is summarized 


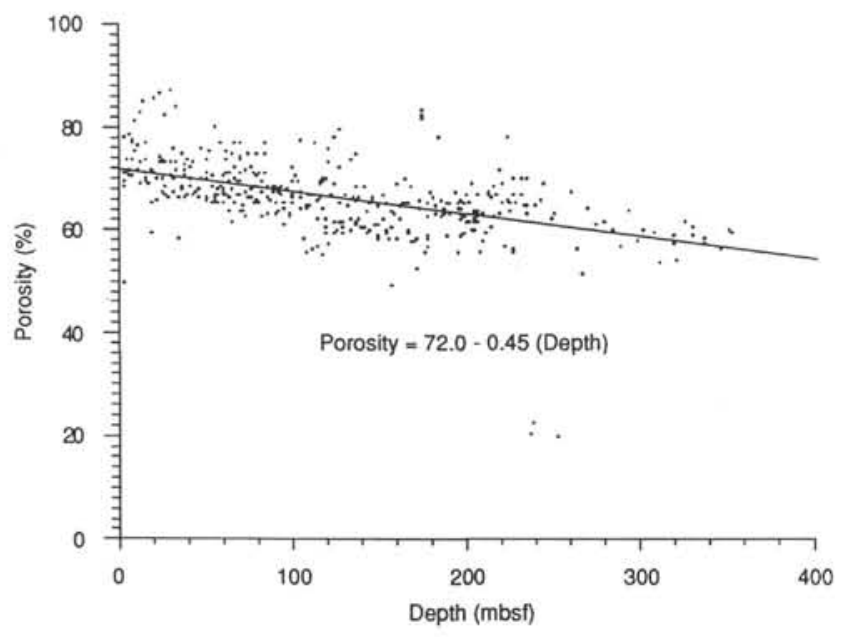

Figure 4. Porosity-depth relationship from shipboard porosity values (see "Physical Properties" sections of individual site chapters in Backman, Duncan, et al., 1988) collected along the carbonate dissolution profile (Sites 707-711).

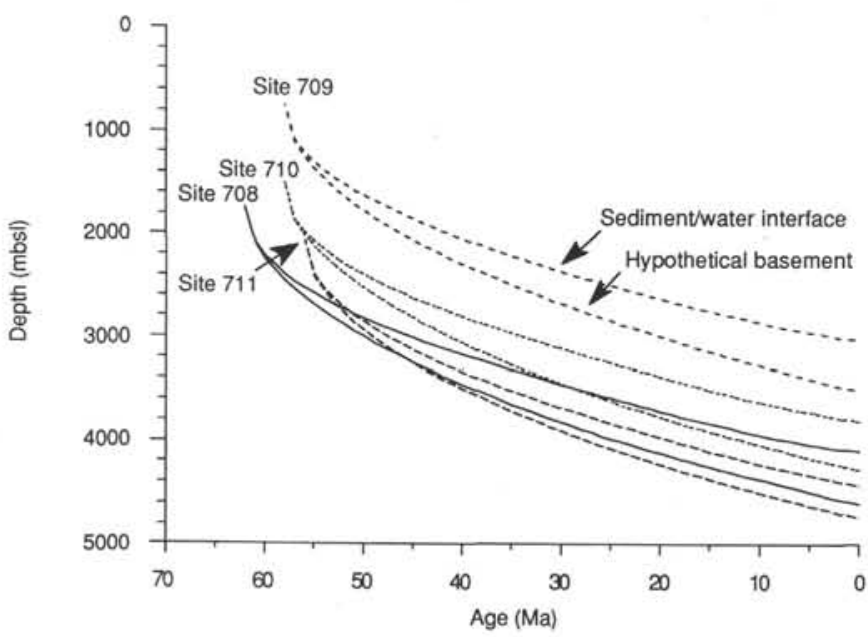

Figure 5. Subsidence curves for Leg 115 sites encountering basement. The sediment/water interface (upper curve) and basement (lower curve) for each site diverge away from the point of emplacement. Sediment thicknesses are decompacted through time.

Table 1. Data used in subsidence history analyses of Leg 115 basement sites.

\begin{tabular}{lccc}
\hline Site & $\begin{array}{c}\text { Age }^{\mathrm{a}} \\
\text { (Ma) }\end{array}$ & $\begin{array}{c}\text { Depth to } \\
\text { basement } \\
\text { (mbsf) }\end{array}$ & $\begin{array}{c}\text { Sediment } \\
\text { thickness } \\
\text { (mbsf) }\end{array}$ \\
\hline 706 & $33.2 \pm 0.5$ & 2367.5 & 47.5 \\
707 & $63.7 \pm 1.1$ & 1928.3 & 376.0 \\
713 & $49.3 \pm 0.6$ & 3070.1 & 155.1 \\
715 & $57.2 \pm 1.8$ & 2477.3 & 211.3 \\
\hline
\end{tabular}

${ }^{a}$ Radiometric dates from Fisk et al. (1989).

in Table 2. Basement at all of the nonbasement sites was emplaced at depths above that expected for normal ocean crust (Fig. 6). The depth of emplacement for Site 709, situated toward the crest of the Madingley Rise, is very anomalous, approaching that of Sites 706 and 713, situated along the volcanic trace of
Table 2. Data used in subsidence history of analyses of Leg 115 nonbasement sites along carbonate dissolution profile.

\begin{tabular}{cccccc}
\hline Site & $\begin{array}{c}\text { Age of } \\
\text { basement }{ }^{\mathrm{a}} \\
(\mathrm{Ma})\end{array}$ & $\begin{array}{c}\text { Total } \\
\text { depth } \\
(\mathrm{mbsf})\end{array}$ & $\begin{array}{c}\text { Age at } \\
\text { total depth }^{(\mathrm{Ma})}\end{array}$ & $\begin{array}{c}\text { Depth of } \\
\text { basement }^{\mathrm{b}} \\
(\mathrm{mbs})\end{array}$ & $\begin{array}{c}\text { Sediment } \\
\text { thickness }\end{array}$ \\
\hline 708 & 62.0 & 234.7 & 34.1 & 4604.6 & 508.5 \\
709 & 58.0 & 353.7 & 47.6 & 3521.1 & 483.3 \\
710 & 58.0 & 209.7 & 33.9 & 4275.7 & 464.0 \\
711 & 56.0 & 249.7 & 50.4 & 4734.5 & 306.8 \\
\hline
\end{tabular}

a Age estimate based on relative distance from mid-ocean ridge crest.

b Hypothetical depth from extrapolating age at total depth to that of basement.

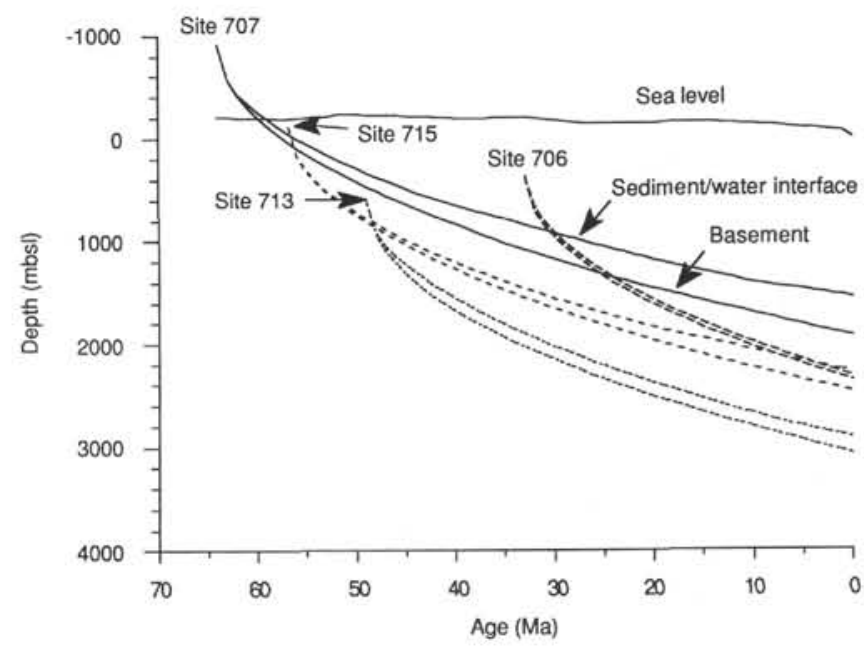

Figure 6. Subsidence curves of hypothetical basement and the sediment/ water interface for the nonbasement sites along the carbonate dissolution profile. Sediment thicknesses are decompacted through time.

the Réunion hotspot. The depth of emplacement for Site 711, on the northern flank of the Madingley Rise, approaches the 2500-m depth predicted for normal ocean crust.

A listing of output in 1-m.y. increments, along with the FORTRAN code used for the analyses, is available upon request. Output includes age, depth of basement, depth of sediment/water interface, original sediment thickness, decompacted sediment thickness, and sediment load.

\section{DISCUSSION}

The sites encountering basement are widely spaced along the volcanic trace of the Réunion hotspot, on both sides of the Central Indian Ridge. In general, the age of volcanism increases northward (see "Introduction" chapter in Backman, Duncan, et al., 1988) from Réunion, which is currently active, to the Deccan Traps of west and central India, dated at 66-68 Ma. Lithologic information, including the texture and alteration of basalts and the nature of the sediments immediately overlying (and often interbedded with) the basalts, are useful in estimating the depth relative to sea level at which the basalts were extruded. In general, the depths of eruption suggested from lithologic information (Backman, Duncan, et al., 1988) are in agreement with depths of emplacement obtained from subsidence history analyses. At Sites 706 and 713, the presence of chilled margins and baked sediment interbeds between basalt flows, provides evidence that these flows were erupted below sea level.

At Site 706, the basal sediments consist of a coarse gravel, including pebbles of reef limestone, suggesting a shallow marine environment of deposition. This compares to a $350-\mathrm{m}$ be- 
low seafloor (mbsf) depth of emplacement obtained from subsidence history analyses. At Site 713 , pelagic sediments overlying basement points to an environment of deposition well below sea level, but a high degree of vesicularity within the basalts is consistent with a shallow depth of eruption. The depth of emplacement from subsidence history analyses is $600 \mathrm{mbsl}$. At Site 715 , reddish brown lateritic(?) alteration within the basalts, which are overlain by very shallow-water reef limestone, is a good indication that the basalts were erupted subaerially.

The depth of emplacement from subsidence history analyses is $183 \mathrm{~m}$ above present sea level. Subsidence history analyses at Site 707 is not in close agreement with the lithologic information at that site. The basalt flows are interbedded with and overlain by shallow-water limestones pointing to subaqueous eruption of the flows. Geochemistry and texture of the basalts suggests a subaerial to very shallow depth of eruption. The depth of emplacement from subsidence history analyses is $920 \mathrm{~m}$ above present sea level, and according to the analyses the site was still above sea level from 63 to $62 \mathrm{Ma}$, during which sediments first began accumulating at the site.

The setting in which the basalts were erupted does not appear to be a major factor in determining the predictability of the subsidence history. As mentioned previously, one might expect oceanic basalts to subside at predictable rates when volcanic eruption is coincident with plate generation at a mid-ocean ridge, and to become less predictable as subsequent volcanism occurs away from the ridge axis in intraplate settings. This expectation is not readily apparent when comparing the lithologic information and subsidence history analysis output to the setting of volcanism emplied from the chemistry of the basalts at the basement sites (Fisk et al., 1989).

The relative abundance of incompatible elements in Leg 115 basalts trends between predominantly plume-derived compositions characteristic of intraplate hotspot settings, such as Réunion, and MORB-derived from athenospheric melting. The trend appears to represent variable mixing of plume and asthenospheric mantle during various stages of coincidence between hotspot and spreading ridge. Sites 707 and 713 are most similar to MORB, yet distinct, reflecting the contribution of plume-derived material. Site 715 is similar to Réunion. Site 706 is intermediate. These results are contrary to the expected predictability of subsidence histories. As was shown, all sites apparently subsided in relatively predictable fashion with the exception of Site 707, where the basement has MORB-like affinities and was apparently emplaced at or near a spreading ridge axis.

The subsidence histories of the nonbasement sites along the carbonate dissolution profile, on the flanks of the Mascarene Plateau, and across the Madingley Rise, are above that predicted for normal ocean crust. Hypothetical basement was emplaced 1750 mbsf at Site 708; 750 mbsf at Site 709 up on the Madingley Rise, well above that for normal ocean crust; 1500 mbsf at Site 710; and 2050 mbsf at Site 711, approaching the level predicted for normal ocean crust. The Madingley Rise would seem to represent a small, positive residual depth anomaly associated with the Mascarene Plateau, probably created by near-ridge-axis volcanism related to the Réunion hotspot.

\section{SUMMARY}

Supported by lithologic information, the subsidence history of the widely spaced sites along the volcanic trace of the Ré- union hotspot indicates that basaltic basement along the trace was emplaced at anomalously shallow depths, but it apparently subsided in a predictable fashion thereafter. Along the bathymetric transect (Sites 707-711) across the northern flank of the Mascarene Plateau and Madingley Rise, basement depths and subsidence histories are anomalous as well, but they do approach what is predicted for normal ocean crust. Subsidence history analyses were initiated to assist historical reconstruction of the CCD in the western Indian Ocean. Peterson and Backman (this volume) present a detailed compilation of sediment mass accumulation rates for the sites along the bathymetric transect.

A combination of carbonate mass accumulation rates with the subsidence history of each site permits the carbonate sediment history to be viewed in an age-depth format, from which the history of carbonate dissolution as a function of depth is deduced. Peterson and Backman (this volume) recognize three major depositional episodes: (1) intermediate accumulation rates and weak dissolution gradients through the Paleogene, (2) reduced accumulation rates through the early and middle Miocene, and (3) high accumulation rates and strong dissolution gradients from accumulation data at Site 711 , but with consistent changes in carbonate mass accumulation rates observed at shallower sites. Several brief CCD excursions near the middle/ late Eocene boundary are suggested between about 39 and 42 $\mathrm{Ma}$. The CCD again crosses Site 711 near the Oligocene/Miocene boundary, rising to an early Miocene high above $4000 \mathrm{~m}$. The CCD appears to shoal twice more while dropping to its present-day level at about $5000 \mathrm{~m}$.

\section{REFERENCES}

Backman, J., Duncan, R. A., et al., 1988. Proc. ODP, Init. Repts., 115: College Station, TX (Ocean Drilling Program).

Fisk, M. R., Duncan, R. A., Baxter, A. N., Greenough, J. D., Hargraves, R. B., and Tatsumi, Y., 1989. Reunion hotspot magma chemistry over the past 65 m.y.: results from Leg 115 of the Ocean Drilling Program. Geology, 17:934-937.

Parsons, B., and McKenzie, D. P., 1978. Mantle convection and the thermal structure of the plates. J. Geophys. Res., 83:4485-4496.

Parsons, B., and Sclater, J. G., 1977. An analysis of the variation of ocean floor bathymetry and heat flow with age. J. Geophys. Res., 82:803-827.

Sclater, J. G., Meinke, L., Bennett, A., and Murphy, C., 1985. The depth of the ocean through the Neogene. In Kennett, J. P. (Ed.), The Miocene Ocean: Paleoceanography and Biogeography. Mem. Geol. Soc. Am., 163:1- 19.

Stam, B., Gradstein, F. M., Lloyd, P., and Gillis, D., 1987. Algorithms for porosity and subsidence history. Comput. Geosci., 13:317-349.

Vincent, E., and Gibson, J. M., 1974. Paleocene and early Eocene microfacies, benthonic foraminifera, and paleobathymetry of Deep Sea Drilling Project Sites 236 and 237, western Indian Ocean. In Fisher, R. L., Bunce, E. T., et al., Init. Repts. DSDP, 24: Washington (U.S. Govt. Printing Office), 859-876.

Date of initial receipt: 29 May 1989

Date of acceptance: 5 January 1990

Ms 115B-188 